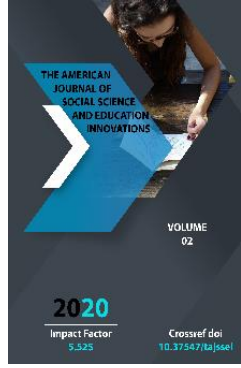

Copyright: Original content from this work may be used under the terms of the creative commons attributes 4.0 licence.

\section{The Main Problems Of Studying Electronic Information And Educational Environment Of The High School: Experience Of Analysis Of Scientific Literature}

Iroda Ilhomovna Khaitova

Lecturer In The Department Of Information And Communication Technologies, Bukhara

Engineering And Technology Institute, Bukhara, Uzbekistan

Shirinboy Sharofovich Olimov

Doctor Of Pedagogical Sciences, Professor, Bukhara State University, Bukhara, Uzbekistan

\title{
ABSTRACT
}

This article describes the problematic issues related to the study of electronic information and educational environment. Considered the degree of knowledge of this topic. The analysis of the literature is considered.

\section{KEYWORDS}

Information and educational environment, electronic information and educational environment, high school, analysis of the literature.

\section{INTRODUCTION}

Issues related to the information and educational environment of the university and the electronic information and educational environment, in particular, have been studied in sufficient detail, despite the fact that the concept of electronic information and educational environment appeared relatively recently. There is a need to identify a number of problematic issues directly related to this topic, as well as authors who have considered them to one degree or another. 


\section{MATERIAL AND METHODS}

Firstly, the problem of the rapid development of information and communication technologies and, as a consequence, the obsolescence of previously developed principles of work in the organization of the educational process.

This problem was reflected in the work of Sh. N. Oymakhmadova [6]. She is considering the use of information and communication technologies in the educational process.

\section{RESULTS AND DISCUSSION}

It should be noted that according to Sh. N. Oymakhmadova, "the future of humanity will largely depend on how well the teaching staff will be trained, how effectively they will use the means of information and communication technologies in the organization of the educational process" [6]. One cannot disagree with this point of view, since the development of almost all aspects of life in a given period of time occurs precisely due to the informatization of society. Therefore, the use of information and communication technologies in education is an important step towards development.

Note that it is the development of information and communication technologies that gives rise to the introduction and functioning of the electronic information and educational environment as a whole. That is why it is necessary to organize training, in particular for pedagogical workers, in working with information and communication technologies.

Secondly, the problem is in the definition of the concept of information and educational environment. This is a problem, since at the moment there is no clearly fixed concept, therefore a rather large group of authors in their works analyzes the concept of the information and educational environment that were proposed by other authors and introduces its concept. These include the work of A. Yu. Nalivalkin [5], T. I. Efanova [2].

So A. Yu. Nalivalkin [5] defines the information and educational environment as a systematic set of pedagogical (educational, methodological), organizational, information, technical conditions aimed at the educational process and its participants. T. I. Efanova [2] believes that this is a systematically organized set of informational, technical, educational and methodological support, inextricably linked with a person as a subject of the educational process.

However, we note that each author, proposing his own concept of the information and educational environment, focuses mainly on aspects of his personal interest. That is why we cannot fully agree with any of the definitions they have proposed and derive our own, generalized one, which will be applied mainly to higher education institutions.

So, the information and educational environment of a university is a system that includes educational, organizational, information and technical conditions that create the opportunity to reveal the abilities of students, as well as to form professionally significant and socially important personality traits.

Thirdly, we note that the electronic information and educational environment is not studied in such detail as the information and educational environment. In this regard, problems arise with the definition of the concept of this phenomenon.

So N. B. Sekulich [7] defines the electronic information and educational environment as a complex, multi-level system that combines program-methodological, organizational and technical resources and the intellectual potential of the educational organization, realized in the process of interaction between 
the participants of the educational and information processes.

However, N. G. Zakrevskaya [3] is trying to make a deeper analysis of this concept, considering opinions on this subject from various sources. As a result, she comes to the conclusion that the electronic information and educational environment is a combination of components containing electronic information and educational resources that contribute to the formation of competences of students using information and communication technologies and operates on the basis of regulatory documents.

The concept proposed by N.G. Zakrevskaya is more comprehensive, however, here you can also include a phrase regarding the provision of electronic information and educational environment for interaction between participants in the educational process.

Fourth, the problem of the non-standardized structure of the electronic educational information environment. The authors who consider issues related to the structure of the electronic informational and educational environment in their works are S. D. Karakozov [4] and S. G. Akhmetova [1].

In the work of S. D. Karakozov [4], the structure of the electronic informational and educational environment means the composition of its components.

Note that this structure is not generalized. It stands out from the point of view of the environment already used at the university. So, the authors distinguish the following components: E-learning portal, implemented on the basis of LMS Moodle; An information portal providing information and organizational support for the educational process; Administrative management information systems and services.
S. G. Akhmetova [1] reveals the most generalized structure of the electronic educational information environment. In her opinion, the structure can be represented by: Educational portals of faculties; Electronic library environment, the official website of the university; Corporate Email Information help systems.

In our opinion, both proposed by the authors of the structure of the electronic educational information environment need to be further developed. Therefore, we can offer the following structure of the electronic informational and educational environment, or rather, the mandatory elements that it should include: the official website of the university; Platform for online courses; The electronic portfolio of students; Electronic library systems.

Note that the structure can also include the possibility of synchronous and asynchronous interaction of participants in the educational process, as well as students' access to electronic educational resources.

\section{CONCLUSIONS}

After analyzing the problems associated with the topic of the functioning of the electronic information and educational environment, we can come to the following conclusions:

Firstly, based on the above analysis of the literature, it can be argued that the topic has a sufficient degree of knowledge.

Secondly, an analysis of the literature gave reason to believe that, although the topic has been sufficiently studied, it still requires further research. Most authors are theorists, therefore, there are very few works based on practical experience working with the electronic information and educational environment.

Thirdly, issues related to the educational information environment are studied to a 
greater extent than aspects of the functioning of the electronic educational information environment. However, it should be noted that, although these concepts are closely related, it is impossible to equate them in any case.

Fourth, the identified problems give reason to believe that further study of this topic is necessary for the possibility of resolving these problems.

\section{REFERENCES}

1. Akhmetova S. G. Development of the electronic educational environment of the university [Electronic resource] // Bulletin of the Perm National Research Polytechnic University. Socioeconomic sciences. 2016. No. 3. Access mode:

https://cyberleninka.ru/article/v/develo pment-e-educational-environmentuniversity

2. Efanova T. I. Information and educational environment of the university [Electronic resource] // A new word in science: development prospects: materials of the VII International Scientific and Practical Conference. Cheboksary, 2016. Access mode: https://interactiveplus.ru/earticles/201/Action201-16199.pdf.

3. Zakrevskaya N. G. Formation of the electronic informational and educational environment of the university [Electronic resource] // Higher education in Russia. 2016. No. 11. Access mode: https://vovr.elpub.ru/jour/article/view/ 894/815.

4. Karakozov S. D. Professionally-oriented components of the electronic educational environment of a pedagogical university [Electronic resource] // Teacher of the 21st
Century. 2017. No. 1. Access mode: https://cyberleninka.ru/ article / v / professionally-oriented-componentselectronic-educational-environmentpedagogical-university.

5. Nalivalkin A. Yu. Analysis of the concept of information and educational environment [Electronic resource] // MRI Bulletin. 2012. No. 1. Access mode:

https://cyberleninka.ru/article/v/ analysis-concepts-informationaleducational-environment

6. Oymakhmadova Sh. N. Primary problems of the introduction of information and communication technologies in the activities of universities // Baltic Humanitarian Journal. 2017 [Electronic resource]. Access mode: https://cyberleninka.ru/ article / v / priority-problemimplementation-informationcommunication-technology-in-motoruniversitiesю

7. Sekulich N. B. Electronic informational and educational environment of the university, principles of construction and structure [Electronic resource] // Bulletin of the Buryat State University. 2016. No. 4. Access mode: https://vovr.elpub.ru/ jour / article / view / 894/815.

8. Shamsitdinova, M. G. (2020). INTERCULTURAL COMMUNICATION AND PROBLEMS OF TEACHING ENGLISH TO THE STUDENTSNONLINGUISTS. Theoretical \& Applied Science, (4), 1024-1026.

9. Shamsitdinova M. THE IMPACT OF INFORMATION TECHNOLOGIES ON DISTANCE EDUCATION DURING PANDEMIC IN THE REPUBLIC OF UZBEKISTAN. PalArch's Journal of Archaeology of Egypt / Egyptology. ISSN: 1567-214X, Netherlands, pp. 89628967

10. Boltabayevich, B. B., \& Shodievna, B. O. (2020). Individual Approach To The 
The American Journal of Social Science and Education Innovations (ISSN - 2689-100x)

Published: December 18, 2020 | Pages: 127-131

Formation Of Artistic And Creative Talents Of Students In Art Schools. The American Journal of Social Science and Education Innovations, 2(08), 637-642.

11. Boltaboevich, B. B. (2020). Formation of the skills of portraying the future teacher of fine arts in pencil drawing. ACADEMICIA: An International Multidisciplinary Research Journal, 10(5), 1122-1127.

12. Baymetov, B. B., \& Sharipjonov, M. S. O. (2020). Development Of Students' Descriptive Competencies In Pencil Drawing Practice. The American Journal of Social Science and Education Innovations, 2(08), 261-267.

13. Salakhova Z., M.Shamsitdinova. ADVANCED PEDOGOGICAL TECHNOLOGIES IN EDUCATION IN THE 21-ST CENTURY. International Scientific Journal Theoretical \& Applied Science, USA, pp. 743-746. 